\title{
PERANAN NINIAK MAMAK DALAM MELESTARIKAN ADAT ISTIADAT MINANGKABAU DITENGAH ARUS GLOBALISASI: STUDI KASUS DI NAGARI PARAMBAHAN DAN NAGARI LABUAH
}

\author{
Nizwardi Jalinus, Fahmi Rizal, Nofri Helmi dan Youmil Abrian \\ Universitas Negeri Padang \\ Author corresponding: youmil@gmail.com
}

\begin{abstract}
Abstrak: Selain memberikan dampak positif dari globalisasi yang terjadi saat ini juga memberikan dampak negatif, yaitu terjadinya pergeseran ditengah-tengah masyarakat, baik itu dari segi sosial, ekonomi dan budaya. Peranan niniak mamak menjadi sangat penting dalam kondisi ini untuk terus melestarikan adat istiadat Minangkabau. Pelastarian adat secara turun temurun dengan sistem konvensional yaitu memberikan pengajaran kepada generasi muda secara langsung dengan kegiatan tatap muka, tentu dalam era gobal ini tidak begitu optimal lagi. Untuk itu perlunya suata upaya dengan pendekatan dengan cara milenial pula yang cocok dengan generasi milenial saat ini. Generasi milenial yang sangat kuat interaksinya dengan teknologi informasi, perlu dipertimbangkan untuk pelestarian adat ini, yaitu pengajaran tentang nilai-nilai adat Minangkabau perlu ditambah dengan memasukan pembelajaran adat istiadat kedalam website atau dapat melalui aplikasi whatsapp pada smartphone, sehingga generasi muda dapat dengan mudah mengaksesnya kapan saja dan dimana saja. Upaya pelestari ini telah dilakukan di Nagari Parambahan dan Nagari Labuah oleh niniak mamak melalui program dari Kerapatan Adat Nagari (KAN) dari kedua nagari tersebut.
\end{abstract}

\section{PENDAHULUAN}

Perkembangan dan sejarah adat Minangkabau tidak bisa dipisahkan dengan Kabupaten Tanah Datar, hal tersebut dengan masih banyak peninggalan-peninggalan sejarah yang dapat ditemukan diberbagai daerah di kabupaten tersebut baik berupa benda peninggalan sejarah maupun tatanan budaya adat Minangkabau yang identik dengan Rumah Gadang. Kabupaten Tanah Datar merupakan salah satu daerah yang menjadi icon Sumatera Barat dalam mempromosikan budaya yang dimilikinya yaitu adat Minangkabau. Filosofi adat Minangkabau yang terkenal dan menjadi pegangan dalam kehidupan bermasyarakat adalah "Adat Basandi Syarak, Syarak Basandi Kitabullah".

Seiring dengan perkembangan globalisasi yang begitu pesat memberikan efek dan pergeseran yang berdampak ditengah-tengah masyarakat, baik itu memberikan efek sosial, 
ekonomi, budaya, dan kebutuhan masyarakat yang semakin tidak terbendung. Globalisasi ekonomi, informasi, dan budaya telah menciptakan sebuah kondisi dunia yang tampak semakin kecil dan semakin kehilangan batas-batasnya. Fenomena yang sering ditemukan saat ini adalah rendahnya minat generasi penerus mereka dalam mendalami dan mempelajari nilai-niali agama dan adat minangkabau yang dikenal dengan pepatah-petitihnya, salah satu nilai budaya yang memiliki keindetikan dengan pepatah-petitif tersebut adalah pidato adat minang (pasambahan) yang slalu ada dalam setiap acara atau kegiatan adat minangkabau. Namun berbagai permasalahan yang terjadi adalah masih banyaknya generasi penerus yang tidak memiliki kemampuan untuk melakukan pidato adat minang (pasambahan).

Globalisasi telah mengintegrasikan berbagai elemen lintas budaya ke dalam sebuah wadah yang disebut 'budaya global' (global culture), sehingga budaya-budaya lokal yang menjadi identitas (khas) suatu daerah telah kehilangan daya tarik bagi generasi penerus. Berdasarkan pengamatan yang telah dilakukan tidak banyak daerah yang mampu merawat dan melestarikan budaya yang menjadi identitas sebuah negara atau daerah dari ancaman globalisasi yang begitu pesat. oleh sebab itu, perlu sebuah upaya yang terencana, terarah, dan sistematis agar budaya minangkabau mampu dilestarikan ditengah ancaman global yang semakin kuat. Dengan meningkatkan peran dan fungsi kelembagaan dan tokoh adat dalam membina lintas generasi agar mampu menjadi pemberi estafet ada kepada generasi selanjutnya.

Kebudayaan Minangkabau sudah menjadi identitas yang melekat ditengah masyarakat dan pemerintahan Nagari Labuah dan Parambahan, sehingga dapat dimaknai adat istiadat minangkabau bagi penduduk setempat merupakan sistem nilai yang fungsinya adalah mendorong dan membimbing masyarakatnya menjawab tantangan yang mereka hadapi sepanjang masa. Sistem nilai tersebut merupakan ciri identitas sebuah kelompok masyarakat budaya yang dicirikan dalam keseharian penduduk Nagari Labuah dan Parambahan. Namun, berdasarkan pengamatan dan wawancara yang telah dilakukan kepada pemuka adat dan masyarakat setempat dapat diungkapkan berbagai persoalan yang tengah dihadapi, diantaranya; pertama, tidak jelasnya ranji adat diwilayah Nagari Labuah dan Parambahan sehingga disaat pengangkatan atau pergantian gelar datuak suatu kaum adat maka terjadi tumpang tindih siapa yang akan diangkat menjadi datuak (gelar adat). Kedua, rendahnya minat pemuda-pemudi setempat dalam belajar dan mendalami nilai-nilai keagamaan islam dan kebudayaan adat minangkabau yang merupakan dua hal yang tidak bisa dipisahkan bagi masyarakat minangkabau. persoalan ini bukan hanya tanggung 
jawab pemerintah setempat tapi juga tugas pokok lembaga adat seperti Kearapatan Adat Nagari (KAN) yang berfungsi untuk mewarisi nilai-nilai adat istiadat kepada generasi penerus. Namun, keberadaanya belumlah optimal terutama dalam pembinaan dan pelestarian adat minangkabau di Nagari Labuah dan Parambahan.

Berbagai kajian dan pertimbangan yang mendalam secara filosofis, strategis maupun praksis, upaya pelestarian budaya minang haruslah dilakukan oleh berbagai sektor terkait baik dari kalangan pemerintah, tokoh adat, akademisi, masyarakat, dll. Karna budaya merupakan sebuah identitas bangsa yang harus dijaga dan dilestarikan keberadaannya agar budaya lokal tidak hanya menjadi 'obyek' ditengah era globalisasi, melainkan 'subyek' yang berperan dalam membentuk perkembangan globalisasi itu sendiri. untuk itu, optimalisasi fungsi Kerapatan Adat Nagari (KAN) Nagari Labuah dan Parambahan perlu dilakukan agar berbagai persoalan adat yang ada dapat diselesaikan secara holistik dan komprehensif sehingga nilai-nilai keagaaman dan budaya alam minangkabau dapat dilestarikan dan diterima oleh kalangan generasi penerus secara turun temurun ditengah arus globalisasi yang begitu deras. Dengan melakukan pengambangan nagari binaan ini upaya mewujudkan Provinsi Sumatera Barat manjadi daerah pariwisata yang religius dan berbudaya akan semakin nyata sesuai dengan tujuan pemerintah setempat.

Berdasarkan permasalahan dan urgensinya yang telah dijabarkan sebelumnya diperlukan sebuah solusi dan program yang terencana, terarah, dan terstruktur dalam melestarikan dan mengembangkan adat minangkabau kepada generasi penerusnya. Pengoptimalan peranan dan fungsi ninik mamak dapat menjadi langkah yang tepat untuk mengatasi permasalahan yang terjadi saat ini.

\section{METODOLOGI}

Data yang disajikan dalam artikelini merupakan hasil pengamatan lapangan pada saat pelaksanaan kegiatan pengabdian masyarakat Nagari Parambahan dan Nagari Labuah, Kecamatan Limo Kaum, Kabupaten Tanah Datar, Provinsi Sumatera Barat pada tahun 2017 sampai tahun 2018. Informasi didapat dari hasil wawancara dari pertemuan rutin dengan masyarakat dan tokoh adat dari kedua Nagari tersebut. Analisis data dan informasi mengunggakan kerangka analisis kelembagaan ( Ostrom, 2005). 


\section{TEMUAN DAN PEMBAHASAN}

\section{Peranan niniak mamak}

Niniak Mamak adalah suatu lembaga adat yang terdiri dari beberapa orang penghulu yang berasal dari berbagai kaum yang ada dalam suku-suku Minangkabau (Azra dkk. 2017). Niniak mamak atau tokoh adat yang dituakan dalam adat Minangkabau mempunyai tugas pokok yaitu menjaga sako (gelar adat) dan pusako (harta). Sako adalah gelar adat Minangkabau yang melekat pada laki-laki Minangkabau ketika diangkat menjadi perangkat adat dalam suatu suku atau kaum. Gelar ini diwariskan secara turun menurun dengan dua jenis pewarisan yaitu dengan sistim koto piliang atau bodi caniago. Pada sistim koto piliang gelar diwariskan kepada kemenakan dekat dari pengulu yang menjabat sebelumnya dengan prinsip "baka mati batungkek budi" maksudnya adalah gelar baru bisa digantikan setelah orang sebelumnya meninggal. Sedangkan pada sistem bodi caniago proses pewarisan gelar dilakukan dengan sistem domokrasi. Anggota suku atau kaum akan mengadakan rapat adat ditingkat persukuaanya dan memilih siapa yang pantas meneruskan gelar tersebut. Pada sistem bodi caniago ini gelar boleh diwariskan selagi orang sebelumnya masih hidup. Menjaga pusako atau harta hulayat persukuan yang umumnya berupa tanah dalam bentuk kebun, sawah atau tanah pemukiman. Peranan niniak mamak ini menjaga pusako ini agar terus diwarisi melalui garis keturunan ibu sesuai dengan sistim matrelinial yang dianut oleh adat minangkabau.

Selain dalam menjaga sako dan pusako ini niniak mamak juga berperan dalam memutuskan perkara yang terjadi dalam tengah masyarakat. Dalam menghadapi suatu perkara untuk mengambil keputusan juga dilakukan dengan dua jenis sistim yaitu sistim bodi caniago dan koto piliang. Pada sistem bodi caniago berpedoman kepada falsafah "tuah dek sakato, mulonyo rundiang dimufakati, dilahia lah samo nyato bi batin buliah dilekti”. Artinya adalah sebuah keputusan dari suatu perkara yang terjadi diambil dari kata sepakat secara bersama dengan prinsip musyawarah dan mufakat. Sedangkan pada sistem koto piliang prinsip yang digunakan dalam memutuskan perkara adalah "nan bagarih nan di pahek, nan baukua nan bakabung, coreng barih dapek diliek, cupang panuah batangnyo bumbuang”. Artinya semua keputusan berdasarkan dari pemikiran kepala suku atau pengulu atau dalam pepatah Minangkabau "manitiak dari ateh". 


\section{Kerapatan Adat Nagari}

Pada setiap nagari di Sumatera Barat memiliki lembaga Kerapatan Adat Nagari, sebagaimana tertuang dalam Peraturan daerah Propinsi Sumatera Barata Nomor: 2 Tahun 2007 Tentang Poko-Poko Pemerintahan Nagari Pasal 1 ayat 13 menyatakan bahwa Kerapatan Adat Nagari yang selanjutnya disebut KAN adalah lembaga kerapatan dari ninik mamak yang telah ada dan diwarisi secara turun temurun sepanjang adat dan berfungsi memelihara kelestarian adat serta menyelesaikan perselisihan sako dan pusako.

Untuk mengoptimalkan fungsi pokok dari KAN maka perlunya peran serta akademisi dari perguruan tinggi sebagai pemberi nilai tambah dan pengokohan eksistensi dari peranan KAN itu sendiri. Melalui pengaplikasian ilmu pengetahuan dan teknologi, model kebijakan, serta rekayasa sosial berbasis riset untuk dapat dimanfaatkan dengan sebaik-baiknya dalam upaya melestarikan adat istiadat Minangkabau dan menciptakan masyarakat yang cerdas dalam memanfaatkan teknologi yang berkembang untuk percepatan peningkatan perekonomian nagari. Peraturan atau tata cara adat dala suatu nagari dirumuskan oleh seluruh anggota KAN, seperti halnya perkawinan, kematian dan pergantian penghulu . Prinsip ini sesuai dengan pepatah adat yaitu adat salingka nagari. Semua aturan dan tata cara dirembukkan oleh anggota KAN yang terdiri dari kumpulan penghulu yang berdomisili dalam satu nagari.

\section{Peranan KAN dalam Era Globalisasi}

Globalisasi merupakan suatu kondisi yang terjadi pada abad 21 ini. Dampak globalisali ini bisa saja negatif atau positif. Salah satu dampaknya adalah tergerus nilai-nilai adat, oleh karena itu peranan KAN sebagai organisasi yang bertugas sebagai pelestarian adat istiadat Minangkabau menjadi suatu hal penting. Hasil penelitian tentang studi kasus pelestarian adat yang ada di Nagari Labuah dan Nagari Parambahan menunjukan bahwa eksistensi dari KAN cukup baik dalam pelaksanaan pelestarian adat istiadat kepada generasi muda Minangkabau di nagari tersebut. Beberapa program dari KAN dari kedua nagari tersebut bukan hanya dengan memberikan ceramah adat saja kepada generasi muda, tapi mencakup kepada aspek lainnya, termasuk hal nya dengan pengembangan ekomomi masyarakat. 
Program-program yang dilaksanakan menunjukan kehadiran dan kepedulian KAN terhadap semua permasalahan yang terjadi pada Nagari. Seperti halnya adanya kegiatan sunat untuk generasi muda yang dilaksanakan oleh KAN. Dampak dari kegiatan ini generasi muda mengetahui keberadaan dari organisasi ini dan selama kegiatan berlangsung seluruh anggota KAN mengajarkan kepada peserta sunat tentang adat isitiadat Minangkabau, bagaimana berbudayanya orang Minangkabau. Hal ini menandakan program pelestarian adat dilaksanakan diiringi dengan kegiatan yang benar-benar dibutuhkan oleh masyakarat. Begitu juga halnya dengan program yang telah diilaksanakan berupa operasi mata katarak gratis, kegiatan ini menghadirkan peranan KAN dalam setiap masalah yang terjadi dimasyarakat dan turut serta aktif memecahkan masalah yang terjadi. Program-program yang dicanangkan oleh kedua KAN dari kedua nagari tersebut merupakan suatu hal yang dapat dicontoh. Hadir untuk memecahkan masalah yang terjadi pada masyarakat dan pada saat kegiatan ini pelestarian adat dilaksanakan.

Berkaitan dengan pelestarian pepatah petitih adat untuk generasi muda, KAN bekerja sama dengan pemerintahan nagari mengadakan lomba pidato adat atau pasambahan. Adanya kompetesi ini memotivasi generasi muda mempelajari pasambahan tersebut. Pelestarian pepatah petitih adat Minangkabau juga dilakukan dengan memanfaatkan aplikasi media sosial yaitu Whapsapp (WA) dengan membuat sebuah grup WA. Pada satu waktu masing-masing dari tokoh adat membagikan tulisan tentang pepatah petitih adat Minangkabau. Pelestarian adat juga memanfaatkan media website nagari, dimana setiap generasi muda Minangkabau dapat mengkases kapan saja. Pemanfaatan Information technology ini penting untuk pelestarian adat. Karena generasi muda saat ini sangat intens dengan internet melalui smartphone mereka. Proses pembelajaran dapat dilakukan kapan saja dan dimana saja.

\section{KESIMPULAN}

Peranan adat dalam era globlalisasi ini penting untuk membentengi generasi muda dari nampak negatif dari globalisasi tersebut. Niniak mamak dan KAN memiliki peranan penting dalam melestarikan adat istiadat ini. Pelestarian dapat dilakukan dengan memberikan program yang dapat memecahkan masalah yang berkembang dimasyarakat dan pada saat pelaksanaan program itulah agenda pelestarian adat dilaksanakan. Berkembangkanya teknologi informasi 
saat ini juga dapat menjadi alat dalam melestarikan adat, dengan menggunakannya pada halhal yang bersifat positif untuk pelestarian adat istiadat Minangkabau.

\section{REFERENSI}

Azra, V F. dkk (2017). Kewenangan Kerapatan Adat Negeri (KAN) dalam penyelesaian Sangketa Tanah Ulayat di nigari Koto Baru kabupaten Solok Berdasarkan PERDA Sumatera Barat No.1 Tahun 2008. Diponegoro Law Journal.

BNN (2016). Hasil Survei Penyalahgunaan dan Peredaran Gelap Narkoba Pada Kelompok Pelajar dan Mahasiswa di 18 Provinsi Tahun 2016. Jakarta: BNN.

Gubernur Sumatera Barat. (2007) Perda Provinsi Sumatera Barat Nomor 6 Tahun 2008 Tentang Kembali Ke Nagari. Padang: Sekretaris Daerah.

Ostrom E. 2005. Understanding Institutional Diversity. New Jersey. Princeton University Press. 